\title{
Biological Markers use in the Diagnosis of Mental Disorders at Work
}

\author{
Sérgio Valverde Marques dos Santos ${ }^{1}$ and Maria Lúcia do Carmo Cruz Robazzi ${ }^{2}$ \\ ${ }^{1}$ Depatment of Nursing School of Ribeirão Preto, University of São Paulo (USP), Brazil \\ ${ }^{2}$ Department of Nursing School of Ribeirão Preto, University of São Paulo (USP), Brazil
}

Submission: November 01, 2018; Published: November 27, 2018

*Corresponding author: Sérgio Valverde Marques dos Santos, Avenida dos Bandeirantes, 3900, sala 101, Campus Universitário - Bairro Monte Alegre, Ribeirão Preto - SP - Brasil

Abstract

Mental disorders are among the main health problems in the work environments and they have caused the loss of working days, disabilities and reduced productivity in several sectors of the labor market. Anxiety, stress, and depression are among the most common mental disorders. Psychosocial factors and work organization have a significant impact on the health of those who exercise it, on their well-being and on their quality of life. Such mental diseases can be diagnosed through biomarkers, which can be used to evaluate human psychobiology and its sociobehavioral processes, enabling to investigate new concepts about the interaction of biological processes with social ones and their impact in the health and behavior of the individual. Thus, salivary biomarkers offer a new approach in Occupational Health, with its ease of collection and wide scope for application. Thus, early diagnosis through biomarkers can reduce the effects of work on workers' mental health, as well as promote contributions to improvements in quality of life and work.

Keywords: Biomarkers; Mental disorder; Work

\section{Introduction}

Mental disorders are among the main health problems in the work environments. They have caused the loss of working days, disabilities and reduced productivity in several sectors of the labor market. Also, they have led to significant economic losses. The impact of mental illness between 2011 and 2013 had a damage of $\$ 16.3$ billion on the world economy. It is estimated that in 20 years, the global economic impact caused by these diseases will be around $\$ 16$ trillion [1,2]. Anxiety, stress, and depression are among the most common mental disorders. Anxiety affects approximately 10 million people worldwide. Stress is considered a true global epidemic. It is present in the lives of most people and has a strong relationship with the high suicide rate worldwide, with an association rate of $90 \%$ of the cases. The depression reaches about $5 \%$ of the world population, that is, 350 million people. It is estimated that in 2020 , depression will be the second largest cause of disability in the world $[3,4]$. Mental illness has affected workers all over the world. Low and middle-income countries are the most prone to this type of disease and have increasing numbers of workrelated cases. This is due to the precarious working conditions that expose the worker to illness determinant factors $[3,5]$.

Thus, morbidity rates can be high and influence those of comorbidities. In this way, they tend to reduce the worker's quality of life, compromising their individual, family, work, social and emotional behavior [2,6]. Psychosocial factors and work organization have had a significant impact on the health of workers on their well-being and their quality of life [7]. Following the logic of the data obtained from the general population, stress, anxiety, and depression are the most commonly reported psychosocial changes among those who work, which can be seen as a consequence of the interaction between other psychosocial variables and the work organization, as well as cause of incapacity to work [8].

Such diseases can be diagnosed according to the symptoms presented in the individual, through scales or inventories mostly presented as the Likert type and often used in research to evaluate populations [9]. Another possibility to diagnose such diseases is the use of specific biomarkers. In recent years, research using biomarkers as a method of disease research has been consolidated as an innovative indicator of great potential for identification and diagnosis worldwide [10]. The most current research has demonstrated the effectiveness of biomarkers for the evaluation of psychosocial risks related to Occupational Health [11-13].

Thus, these markers tend to be a safer and more effective for the diagnosis of mental illness in workers and other population. Thus, they can promote faster diagnoses and better prognosis to those who are affected by mental illness, providing better working and living conditions to these people. 
Biomarkers or biological markers can be used to evaluate human psychobiology and its socio-behavioral processes [14]. Biological markers can be understood as substances or their biologically transformed products (blood, saliva, hair, urine, feces), as well as any early biochemical changes whose determination in biological fluids, tissues or exhaled air, assess the intensity of the exposure and the risk to health [15]. They consist of predictive tests for diagnoses of some pathology such as intestinal and liver cancers, as well as mental changes such as stress, anxiety, and depression. Their use can be considered a search strategy and health surveillance [16]. Its search in saliva has been increased. Researchers have been working to verify the reaction of proteins, such as chromogranin A, in response to stress and anxiety, due to its greater variability of concentration occurring in the saliva. Also, measurements of cortisol, amylase, and immunoglobulin have also been studied as potential biomarkers of stress, using saliva samples. This is due to the fact that the collection of this biological material is not an invasive procedure and, possibly, it does not cause stress in the individual, enabling a more effective result on its real health condition $[11-13,17,18]$.

Then, biomarkers enable to investigate new concepts about the interaction of biological processes with social ones and their impact on the health and behavior of the individual [14], including those who work.

\section{Conclusion}

The biomarkers offer a new approach in Occupational Health, with its ease of collection and wide scope for application. Psychological risk prevention and early diagnosis can reduce the effects of work on workers' mental health, as well as promote contributions to improvements in quality of life and work. The identification of aggressive factors and mental illness in the work environment can be considered agents of change. This identification can be done with biomarkers. Once these factors are identified, workers and managers can discuss them and propose possible solutions to minimize their effects, favoring the occurrence of a healthier situation and greater labor productivity.

\section{Acknowledgment}

To the Fundação de Amparo à Pesquisa do Estado de São Paulo - FAPESP.

\section{Conflict of Interest}

Author declares no conflict of interest.

\section{References}

1. Nieuwenhuijsen K, Verbeek JH, de Boer AG, Blonk RW, Van Dijk F] (2006) Predicting the duration of sickness absence for patients with common mental disorders in occupational health care. Scand J Work Environ Health 32(1): 67-74.

2. Organización Mundial de la Salud (2013) Plan de acción sobre salud mental 2013-2020. p. 2-54.

3. WHO (2015) Mental disorders: fact sheet $n$ no 396. World Health Organization.

4. Ticas AR, Medina MT, Mesa X, Paredes Y, Barahona Y, et al. (2012) Estudio de síndrome de "burnout", depresion y factores asociados en los practicantes internos del hospital escuela. Revista Fac Ciencia Medica 9(1): 14-20.

5. Oliveira GF, Carreiro GSP, Ferreira Filha MO, Lazarte R, Vianna RPT (2010) Risco para depressão, ansiedade e alcoolismo entre trabalhadores informais. Rev Eletr Enf 12(2):272-277.

6. Santos EG, Siqueira MM (2010) Prevalência dos transtornos mentais comuns na população adulta brasileira: uma revisão sistemática de 1977 a 2009. J Bras Psiquiatr 59(3): 38-246.

7. Theme Filha MM, Costa MAS, Guilam MCR (2013) Estresse ocupacional e autoavaliação de saúde entre profissionais de enfermagem. Rev Latino-Am Enf 21(2): 1-9.

8. Serafim AC, Campos ICM, Cruz RM, Rabuske MM (2012) Riscos psicossociais e incapacidade do servidor público: um estudo de caso. Psicol cienc prof 32(3): 686-705.

9. Cunha JA (2001) Manual da versão em português das Escalas de Beck. São Paulo: Casa do Psicólogo; 2001.

10. Wang, H, Zhang H, Deng P, Liu C, Li D, et al. (2016) Tissue metabolic profiling of human gastric cancer assessed by $1 \mathrm{H}$ NMR. BMC Cancer 16(371): 2-12.

11. Staufenbiel SM, Penninx BW, Spijker AT, Elzinga BM, Van Rossum EF (2013) Hair cortisol, stress exposure, and mental health in humans: A systematic review. Psychoneuroendocrinology 38(8): 1220-1235.

12. Maschirow L, Khalaf K, Al-Aubaidy HA, Jelinek HF (2015) Inflammation, coagulation, endothelial dysfunction and oxidative stress in prediabetes - Biomarkers as a possible tool for early disease detection for rural screening. Clin Biochem 48(9): 581-585.

13. Abell JG, Stalder T, Ferrie JE, Shipley MJ, Kirschbaum C (2016) Assessing cortisol from hair samples in a large observational cohort: The Whitehall II study. Psychoneuroendocrinology 73: 148-156.

14. Chrousos GP, Gold PW (1992) The concepts of stress and stress system disorders. JAMA 267(9): 1244-1252.

15. World Health Organization. Biological Monitoring of Chemical Exposure in the Workplace. Geneva, Switzerland: WHO. 1996.

16. Soreide K, Watson MM, Lea D, Nordgard O, Soreide JA, et al. (2016) Assessment of clinically related outcomes and biomarker analysis for translational integration in colorectal cancer (ACROBATICC): study protocol for a population-based, consecutive cohort of surgically treated colorectal cancers and resected colorectal liver metastasis. J Transl Medic 14(1): 192.

17. Obayashi K (2013) Salivary mental stress proteins. Clin Chim Acta 425 : 196-201.

18. Toda M, Den R, Hasegawa-Ohira M, Morimoto K (2013) Effects of woodland walking on salivary stress markers cortisol and chromogranin A. Complement Ther Med 21(1): 29-34. 
Your next submission with Juniper Publishers will reach you the below assets

- Quality Editorial service

- Swift Peer Review

- Reprints availability

- E-prints Service

- Manuscript Podcast for convenient understanding

- Global attainment for your research

- Manuscript accessibility in different formats ( Pdf, E-pub, Full Text, Audio)

- Unceasing customer service

Track the below URL for one-step submission https://juniperpublishers.com/online-submission.php 